\title{
The Language of Power in the Present-Day Digital Media Discourse and Its Effect on Young People's Consciousness
}

Alla Guslyakova, ${ }^{+*}$ Nina Guslyakova, ${ }^{1}$ Nailya Valeeva ${ }^{\ddagger}$ Irina Vashunina, ${ }^{i}$ Maria Rudneva, ${ }^{\beta}$ and Julia Zakiroval

\section{Abstract}

This study focuses on the notion of power as a way of conceptualisation, representation and functioning in the Russian and English-speaking media discourse and its role in the life of the younger generation of the third millennium. Power and its language have always remained an actual research question of interdisciplinary scientific analysis. However, studying young people's linguistic and paralinguistic perception of power in the era of digitalisation becomes extremely important due to an empowering role young adults have started playing in modern society employing new media and their discursive communication there. The study regards the theoretical background of the phenomenon of power, based on A. Gramsci's hegemonic approach. The authors of the research suggest that the media discourse is a hegemonic form of power that maintains its position through the elaboration of a particular worldview, which makes a significant impact on young individuals, the so-called net-generation. The study relies on free-associative and graphic experiments to analyse and perceive "power" concept and its influence on young individuals' consciousness. Results indicate that both Russian and English-speaking media discourse represents "power" through the prism of anthroponyms as well as toponyms. Besides, the findings of the free-associative experiment, conducted among young adults, demonstrated the dominance of the lexical units belonging to the same grammatical class of words as the stimulus word "power". Furthermore, a graphic experiment revealed young people's emotional evaluations of power in media discourse communication. As such, the results suggest that "power" is a natural, complex and multifaceted linguacultural and social phenomenon realised through a variety of linguistic and paralinguistic means, and it produces a dualistic effect on young people's consciousness through their interaction in the media discourse space.

Keywords: Power; Media Discourse; Young People; Consciousness; Free-Associative Experiment; Graphic Experiment

\footnotetext{
${ }^{+}$Associate Professor of the Department of Foreign Languages, Ecological Faculty, RUDN University; Associate Professor of the Department of Contrastive Linguistics, Institute of Foreign Languages, Moscow State Pedagogical University, Russian Federation

${ }^{*}$ Corresponding Author, Email: aguslyakova@bk.ru

'́Professor of the Department of Technology and Psychological and Pedagogical Disciplines, Faculty of Science and Technology, South Ural State Humanitarian Pedagogical University, Russian Federation, Email: guslyakovani@cspu.ru ₹Professor, Head of the Department of Foreign Languages, Ecological Faculty, RUDN University, Russian Federation, Email: ngvaleeva@yandex.ru

' Professor, Russian Foreign Trade Academy, Ministry of Economic Development of the Russian Federation, Russian Federation, Email: vashunina@yandex.ru

${ }^{\beta}$ Associate Professor of the Department of Foreign Languages, Ecological Faculty, RUDN University, Russian Federation, Email: maria_rudneva@list.ru

ìAssociate Professor of the Department of Foreign Languages, Ecological Faculty, RUDN University, Russian Federation, Email: julia_nigma@mail.ru

(C) 2020 Guslyakova et al. This is an Open Access article distributed under the terms of the Creative Commons Attribution License (http://creativecommons.org/licenses/by/2.0), which permits unrestricted use, distribution, and reproduction in any medium, provided the original work is properly cited.
} 


\section{Introduction}

At all times, humanity has been concerned with the problem of gaining and retaining power. Ironically, a person reflects on power in his whole conscious life (Picoult, 2009), and even in an advanced age one tries to comprehend the essence of this paradoxical phenomenon. "Power is everywhere, not because it embraces everything, but because it comes from everywhere" (Foucault, 1979: 63). It is dynamic in its usage, it can transform from one form of substance to another one. Thus, it disturbs the best minds of our history and modernity (Plato, Aristotle, Machiavelli, Hobbes, Nietzsche, Adler, Toffler and others). Moreover, the issue of studying the mechanisms of power realisation is multidimensional.

The elusive and value-laden nature of power has led to a plurality of theoretical and conceptual approaches and is the object of an interdisciplinary study of such scientific branches as philosophy, psychology, political science, sociology, journalism, and linguistics.

From our viewpoint and regarding our scientific interests, the phenomenon of power is a crucial category of media discourse. It primarily reflects the meaning of the existence of the media environment as the fourth power in society (fourth estate), alongside three other branches of the government: legislative, executive and judicial ones. The category of discursive power is the core of an immense media mechanism that exists in the media space in its various forms: content, cognitive, sociolinguistic, rhetorical and pragmatic. We support the idea that the notion of power and the media discourse must be considered as a single whole organism, existing and functioning in its harmony and constancy.

Marshall McLuhan, Canadian philosopher once rightly noted that the medium is the message (McLuhan \& Fiore, 1967) and one of the most vulnerable groups of people who are exposed to this media message and its power today is the younger generation or the so-called "Generation Me" (Croteau \& Hoynes, 2014: 318) - the modern youth as individuals who have an extreme focus on the self and immediate networks of their friends. The massive technological revolution of the modern society and the popularisation of digital devices in everyday life make a powerful effect on the younger generation even more robust than we may expect because their digital assistants (smartphones, tablets, laptops, and smartwatches) are turning into their "alter ego", that is their best friend, advisor and mentor.

Therefore, this article seeks to investigate the role of various linguistic and extralinguistic (paralinguistic) signs of the manifestation of "power" concept in the Russian and Englishlanguage modern media discourse environment and its effect on the young people' consciousness in the third millennium.

The primary research objectives of the study are:

- an analytical review of the works dedicated to the problem of the relationship between the concepts of language, power and media discourse in social sciences and humanities;

- a theoretical background interpretation of young individuals' consciousness exposure to the mechanism of power in the digital media epoch;

- the analysis of "power" concept (its structural and semantic features) in the corpus of media texts in print and electronic editions of the Russian and English mass media;

- presenting and discussing the results of free-associative and graphic experiments that allow understanding the nature of the relationship between the youth and "power" concept and estimating the influence degree of this phenomenon on young people's consciousness in the present-day media discourse space.

\section{Literature Review}

Several aspects of the definition of power adopted in this research are noteworthy. Figuratively, power is perceived from two positions: as something created by man (realised in the metaphors of the architectural structure) 
and as something naturally existing (metaphorically presented as a living being, a natural phenomenon) (Shabanova, 2011). The conceptual representation of power is one of the most critical elements in the linguistic world image of each nation. The theoretical concept which we support in our research analysis of power in the media discourse is called hegemony. The notion of hegemony was drawn from the work of Antonio Gramsci (1971), an Italian Marxist who wrote in the 1920 s and 1930s, and it connects questions of culture, power, and ideology. Hegemony operates at the level of common sense in people's expectations about their social life and based on things which act as a natural phenomenon. Power is a natural phenomenon in society. Perhaps, sometimes it can even be perceived to be beyond human control, and it is hegemonic.

Sociologist Stuart Hall (1982), the leading voice of British cultural studies, has provided a sophisticated analysis of the mass media institutions in their relation to the conception of hegemony. He argued that mass media are one of the leading sites where the work of hegemony is exercised. Therefore, we assume that since the mechanism of power is incorporated into the concept of hegemony, power itself becomes the main site of the media environment.

The mechanism of power realisation within linguistic and media scientific knowledge is also actively considered at a conceptual level of modern reality perception and is the subject of special research in several works by Russian and foreign scholars (Apresyan, 1997; Bolinger, 1980; Fairclough, 2001; Fowler, 1991; Hodge \& Kress, 1993; Issers, 2009; Kara-Murza, 2018; Karasik, 1996, 2004; Maslow, 2008; Philo, 2007; Rudakova, 2004; Sedov, 2004; Shabanova, 2011; Sheigal, 2000, 2001; Simpson \& Mayr, 2010; Slyshkin, 2002; Tokarev, 2000; Van Dijk, 2008, 2009). The key point here is that for critical discourse researchers such as T. van Dijk (2008, 2009) and N. Fairclough (2001), the term discourse correlates with power and social interests. One of the causal effects of texts which have been of significant concern for critical discourse analysis characterises by establishing, maintaining and changing social relations of power, domination and exploitation (Philo, 2007).

American researchers Paul Simpson and Andrea Mayr (2010) have stated that modern media institutions have become inextricably linked to power. The media discourse is a hegemonic form of power that maintains its position, not through force, but through the elaboration of a particular world view, an ideology, or a particular notion of common sense, which is widely infused into everyday cultural practices. This results in people (especially young individuals) consenting to power even when it may not be in their best interest.

Moreover, in the present-day digital epoch new bits of knowledge are produced continuously, circulated and consumed as discourses (economic, organisational, managerial, political or educational) and disseminated through discourse technologies (Simpson \& Mayr, 2010). Contemporary society is knowledge- and discourse-based not only in their economies but also, in their expectations about how people should lead their private lives and conduct their relationships. The new media discourse can shape people's lives, habits, opinions and beliefs. One can feel how the power of language is disseminated through texts of different sorts and is transmitted through the media and modern information technologies. The new media are top-heavy with expert advice on how people should conduct almost every aspect of their lives and the language of the media discourse is not a neutral channel (Negm, 2015), but the tool for influence, guidance, manipulation and control.

The perception of the language of power in the present-day media discourse nowadays can be interpreted through simple models (Croteau \& Hoynes, 2014), emphasising direct media influence, to more sophisticated analyses highlighting the interaction of the media and the audience. At the pinnacle of this complex 
interaction, there exists the most "sensitive" social group which can be easily exposed to the power of the contemporary media discourse and inculcated by its multiple ideas, and that is the younger generation of the individuals born and living in the digital age of the XXI century.

There is a clear tendency that the younger the person is, the stronger his or her mind correlates with the digital media environment. In our opinion, the new media discourse may play a powerful role of a young individual's "confidante" as its technological features allow being an extremely intellectual expert and giving reasonable advice on different everyday academic, professional and personal issues. The findings of our research we introduce below help to shed the light on the questions about the relationships between the third millennial youth, the language of power and their "powerful" communication in the new media discourse space.

\section{Materials and Methods}

This study uses three empirical stages. In the first stage, we analyse the corpus of the print and electronic versions of the following Russian and English-language media over the past decade (2009-2019): Ria Novosti, Kommersant.ru, Kommersant Vlast, Interfax.ru, RBK Group (RosBiznesKonsalting), Newspaper.ru, Moskovskij Komsomolets, Arguments and Facts, The Moscow Times; The New York Times, The Times, The Guardian, The Telegraph, BBC News, The Sydney Morning Herald, The Washington Post, The Toronto Star.

The study of such extensive media materials allowed us to identify several important patterns in the functioning of the notion of power in the media discourse of Russia, the United Kingdom, the USA, Australia and Canada. These patterns closely correlate with the theoretical approaches to the concept of power introduced in the works of A. Gramsci, A. Shabanova, M. Foucault, D. Croteau, W. Hoynes, T. van Dijk, N. Fairclough, P. Simpson and A. Mayr, that were outlined above. That is, power is a ubiquitous, natural, ideological, cultural and social phenomenon which is often introduced in very simple models, objects and personalities.
At the second stage, we analysed the structural and semantic components of the notion of power in the media discourse and conducted a free-associative experiment with the participation of 50 bachelor students at Moscow State Pedagogical University (MPGU) and Peoples' Friendship University of Russia (RUDN). Both Russian and international students (especially the English-speaking students) enrolled at MPGU and RUDN universities were interviewed about their attitude towards the notion of power as well as its representation and functioning in the present-day media environment.

In the third stage of the research, we conducted a graphic (drawing) experiment for a deeper understanding of young people's perception of power. It is essential to understand that drawing is nothing more than a display of thoughts, feelings, attitude and character of a person; it acts as a means of penetrating the individual's spiritual space (Jung, 1979).

In the framework of this study, the analysis of drawings helped us clarify and expand the perception of power in the minds of young people since a picture expresses the "inexpressible" in words. Moreover, it should be noted that this "inexpressible" can be purposefully portrayed using the means of graphics and painting, and appear on the drawings as if unnoticed by their creator.

This unconscious part of the external representation of the image (which is usually the image of non-professional, amateur artists) provides especially valuable material for our research. In addition to the content of the images, we also explored their forms and considered the semantics of all elements of the form: composition, geometric shape, lines, size, colour. These elements are also multivalued, although to varying degrees (Stepanov, 2015). It is well known that colours have extensive semantics, with some colour values practically mutually exclusive. For example, red is a colour of blood as well as a colour of motherhood, love, war and revolution. Furthermore, each time it is necessary to determine what exactly the subject 
had in mind, using specific elements of the form or colour.

Therefore, for this study, we interviewed 31 students enrolled in the magistracy of Russian Foreign Trade Academy (Moscow) to draw (on an A4 sheet) the associations they have with the word "power" when they communicate in new media discourse space. The assignment was as follows: "Please, draw "power" concept as you can imagine it." At the same time, students were also allowed to write individual words in the figure (only if they feel the impossibility of depicting something). The execution time was 10 minutes and received $100 \%$ responses. The results are discussed in the following section.

\section{Results}

Power often remains hidden, and it is usually hidden behind certain critical words in the media context, which have specific hints or cues (Fairclough, 2001). Our results illustrate very clearly that the basic, pragmatic feature of the concept of power in the media discourse is represented by a wide range of proper names, among which there are powerful anthroponyms such as Vladimir Putin, Dmitry Medvedev, Kim Jong-un, Xi Jinping, Donald Trump, Angela Merkel, Theresa May, David Cameron, Elon Mask, Boris Johnson, Barack Obama, Joseph Kony, Immanuel Kant, Marcus Aurelius, Bill Gates, Hillary Clinton, Greta Thunberg, Narendra Damodar Modi and many others. For examples:

On 24 June, following the Brexit referendum in favour of leave campaign, David Cameron announced his surprise resignation that transformed the country's political landscape shattering the continent's postwar settlement (Savage \& Fisher, 2016).

Why Medvedev sent school teachers to the business? (Seliverstova, 2016).

President Trump pressed Vladimir V. Putin on Russia's interference in the 2016 United States election but did not dwell on the subject. Their encounter lasted two hours and 15 minutes, far longer than expected (Hirschfeld \& MacFarquhar, 2017).
Teenage climate activist Greta Thunberg said she was surprised and honoured Wednesday to be named Time's youngest Person of the Year... (Jordans, 2019)

In addition, toponyms are the next significant lexical units which reflect the conceptual representation of power: Moscow, London, Ankara, the Kremlin, Brussels, Ukraine, North Korea; USA, Washington, Beijing. The names of political parties, corporations, international military and economic organisations: Apple, Aeroflot, Gazprom, United Russia, UN (United Nations), NATO, WTO, WADA, etc. For examples:

Syria's five-year conflict has taken on an ethnic dimension, with Kurdish groups carving out their regions and periodically battling groups from Syria's Arab majority, whose priority is to overthrow Assad (Black, 2016).

Russia's Aeroflot will cancel Boeing 737 Max order if safety issues are not solved (The Moscow Times, 2019).

Beijing Exhibiting New Assertiveness in the South China Sea (Perlez, 2012).

When describing the mechanism of power in the Russian and English-speaking media discourse, one can often find various adjectives that characterise the power structures: legal, executive, legislative, patriarchal, republican, authoritarian, judicial, public, presidential power. For examples:

Notice the Newtonian physics of America's Madisonian system. Barack Obama's Wilsonian hostility to the separation of powers, expressed in his executive authoritarianism, is provoking equal and opposite reactions from the judicial and legislative branches (Will, 2013).

Donald Trump uses presidential power to commute prison sentence for the first time (Vale, 2017).

It is obvious from the examples introduced above that the syntactic level of the lexemes of "power" is represented by one, two and three- 
unit words - president, state, government, dictator, family; political parties, state apparatus, state organs, sworn enemies, kinship ties, power vertical, party nomenclature, terroristic group, ruling class; Minister of Foreign Affairs, State Duma Speaker, Member of Parliament, Head of State. For examples:

This is the beginning of the construction of the future power vertical in 2024 (Drize, 2019).

...between Mrs Clinton and Theresa May, Britain's new prime minister (and to a certain extent, Nicola Sturgeon, the first minister of Scotland), two more women are in the public eye, not as spouses of world leaders, but as the leaders themselves - or the potential leaders. And they are, quietly but unquestionably, changing the rules about what it means to look like a president or prime minister (Friedman, 2016).

The phrases such as "bank account in Switzerland", "a car with a flasher", "shaping people's outlook", "to influence on changes", "high position in society", "new way to influence people", "an influence on other's opinion", "a powerful tool" are extremely popular in the media discourse space of Russia and the Englishspeaking world. For examples:

Social media is a powerful tool to share information across international borders -So what?

Today, preconceived notions and ideals will continue to be challenged, and those who use the medium with purpose have the opportunity to influence someone across the world in a positive way (Cohn, 2016).

The moral and ethical character of "power" concept is expressed by nouns (duty, justice, honour, reason, decency, trust, morality; honesty, integrity, kindness) and adjectives (principled, successful, organised, ambitious, purposeful, proud, hard-working, strong, trusting). At the syntactic level, individual lexemes, as well as phrases (mental abilities, willpower, iron will, the hardness of character, strong character; belief systems, knowledgeable people) and more extended variants of associates in the American version dominate (doing the right thing, sympathy with other people, etc.). For examples:

All honour must know and conscience. The Supreme Court clarified that claims for the protection of honour and dignity should not kill the media. (Rubnikovich, 2010).

Hillary Clinton has a major honesty problem... (Cillizza, 2016).

Brain family deportation case 'about doing the right thing'. An Australian family who wants to stay in the UK could be deported from their home in the Highlands (BBC News, 2016).

\section{Data Analysis of a Free-Associative Experiment}

Our experiment allowed distinguishing two groups of associations - syntagmatic associations (40\%) and paradigmatic ones $(60 \%$ correspondingly). The results of the experiment show that the responses of both Russianspeaking and English-speaking interviewees are dominated by lexical units belonging to the same grammatical class of words as the stimulus word "power" (Benveniste, 1995; Apresyan, 1997). Next, we identified four types of paradigmatic associations: 1 ) synonymous (30\% of the total number of paradigmatic associations) (power ability, will, control, dominance, influence, strength, might, force, muscles, energy, government etc.); 2) antonymous (25\%) (power - lawlessness, coercion, tyranny, despotism, dictator, violence, injustice etc.; power - illegal, criminal, violent, unlawful etc.); 3) hyponymic (20\%) (power - law, legislation, budget, democracy, monarchy, anthem, flag, throne, economy, king, prince, judge etc.); and 4) hyperonymic associations (25\%), which for the most part intersect with synonymous (power state, control; industry, majority etc.).

The associates obtained as a result of the experiment refer to the concepts with which a young person operates in his or her daily communication. This means that the associates reflect the picture of the world based on the 
specific features of the Russian and English languages as well as their culture.

\section{Data Analysis of a Graphic Experiment}

Figures 1, 2 and 3 below demonstrate our young respondents' attitude towards the concept of power in the new media discourse environment through its graphic image.

Emotional evaluations, as well as expression, are present in the drawings. This evidence testifies to the unique personal meaning that the respondents put into "power" concept, demonstrating both positive and negative emotions concerning this phenomenon.

From the viewpoint of dynamics, all the drawings are static which characterises, in turn, the power as something solid and permanent. There are geometric forms in the images, characterised by visual stability.

If we summarise the data of the graphic experiment and try to perceive how young individuals visualise the notion of power today, we will get the following principles.
- Power is a natural, hegemonic and hierarchal phenomenon. An object of power is above others and is often more significant than them.

- Power is stable and constant.

- Half of the cases demonstrate that power is associated with people while a third of the cases are related to the attributes of power.

- For $55 \%$ of the respondents, the attitude to power is more neutral than positive or negative (as found in $34 \%$ of the responses).

- For the respondents, the stimulus "power" in $75 \%$ of cases does not have personal meaning. Nevertheless, at the same time, young people understand that "power" is ubiquitous. In the modern digital world, power is naturally embodied in the media discourse space, which can make a significant impact on young individuals' mindset and behaviour.

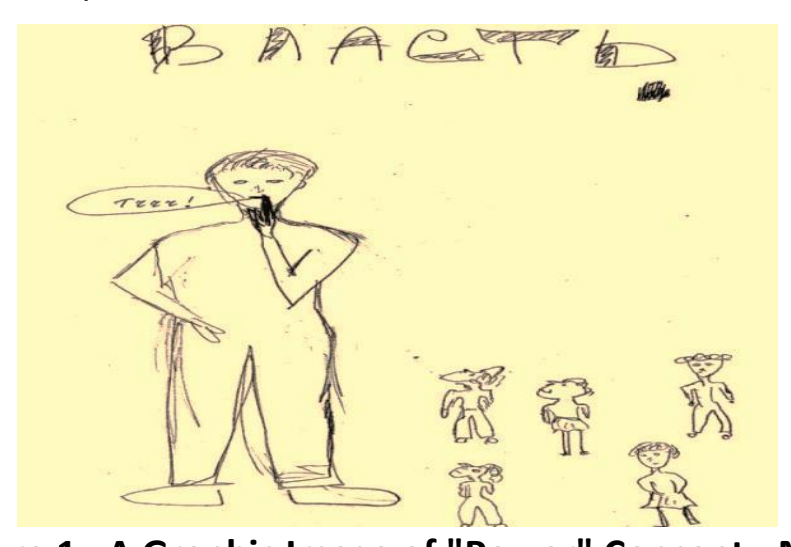

Figure 1: A Graphic Image of "Power" Concept - Man Source: Created by the Authors

BADCTB

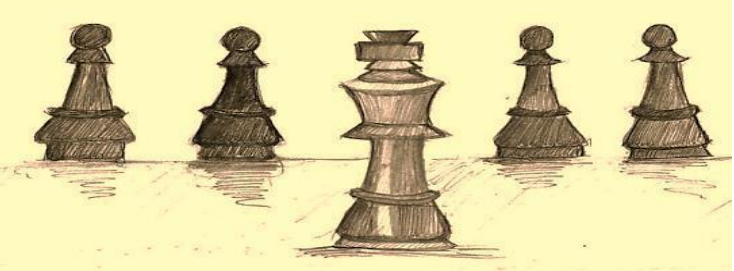

Figure 2: A Graphic Image of the "Power" Concept - Chessmen Source: Created by the Authors 


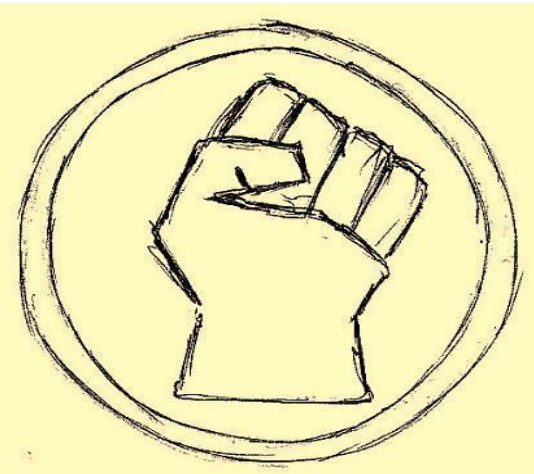

Figure 3: A Graphic Image of the "Power" Concept - Clenched Fist Source: Created by the Authors

\section{Discussion}

Language gains power only when it is used by people who have power (Vodak, 1997). However, at the same time, the language itself provides the speakers with a whole arsenal of means of power manifestation and its exercise. It can be a variety of language units, stylistic means, speech acts and genres, communicative approaches and their graphic content and image (Van Dijk, 2008). Modern young people have all the social and linguistic instruments to gain and exercise the phenomenon of power, and they are already doing it. Nevertheless, on the other hand, the younger generation is sensible enough to be cautious and deal with power mechanisms wisely and constructively. And this is probably the best way of young individuals' perception of "power" concept and its language representation in the new digital epoch.

Media discourse is an affluential mechanism of sustaining power. Theoretical understanding of the problem of power in Russian and Englishspeaking media discourse space, as well as free associative and graphic experiments, allow us to suggest that power is a natural, hierarchical, static, personified driving force, causing controversial, emotional and expressive reactions in society. At the same time, power is metaphorical and attractive, with a multiple media image and international recognition. Therefore, the conceptual representation of power will always cause a large number of controversies and discussions in the scientific world, social sciences and linguistics, in particular.
The problem of studying the mechanism of power, its functioning and impact on young adults as well as people of other age groups in the modern media discourse space are undoubtedly relevant and multifaceted. It remains open to further scientific analysis and reflection, as evidenced by the results of theoretical and empirical research presented in this scientific project.

\section{Conclusion}

The purpose of the current study was to determine the language of power in the current digital media discourse environment and its effect on young people's consciousness. Modern humankind exists in an exciting time when the technological revolution has achieved scientific results that real and digital worlds represent the unity which can hardly be separated in an individual's consciousness. We can think of technological determinism as an approach that identifies technology, or technological developments, as the central causal element in processes of social change. Technological determinists emphasise the "overwhelming and inevitable" effects of technologies on users, organisations, and societies (Lievrouw \& Livingstone, 2006:21). As for manifestations of contemporary digital ideologies, new media discourses form individual and collective consciousness, and through the repetition of ideas and statements, they solidify knowledge as well as reflect, shape and enable social reality.

Thus, the new media discourse of the third millennium does possess the power to affect significantly people's worldview, especially 
young people's consciousness. However, we may assume that young individuals also influence the further evolution of the new media discourse and various language forms it exploits by generating media content, sharing it with others and actively communicating with each other in the media discourse space.

One of the bright examples of such a media effect is present-day young bloggers who can produce a strong impact on both the media discourse space they operate and their subscribers and followers.

We suggest that in the modern world of technological advances, there is a powerful mutual effect that both the new media discourse and young people may have on each other. The media shape the youth's language and consciousness but at the same time, young adults make their own choice what language they would like to speak to the media, how they understand the language of power, what the concept of power means to the modern youth and what are the reasons for such interpretation.

\section{References}

Apresyan, R.G. (1997). Strength and violence of words. The Man, 5, 133-137.

BBC News. (2016). Brain family deportation case 'about doing the right thing'. Retrieved August 2, 2016, from

https://www.bbc.com/news/av/uk-scotland36939846/tom-conti-i-II-pay-3000-to-preventdeportation

Benveniste, E. (1995). Dictionary of IndoEuropean Social terms. Moscow: ProgressUniverse.

Black, I. (2015). Syria crisis: where do the major countries stand? The Guardian. Retrieved August 20, 2016, from

https://www.theguardian.com/world/2015/sep /29/syria-crisis-where-do-the-major-countriesstand

Bolinger, D. (1980). Language - the Loaded Weapon: The Use and Abuse of Language Today. London and New York: Longman.
Cillizza, C. (2016). Hillary Clinton has a major honesty problem after New Hampshire. The Washington Post. Retrieved July 25, 2016, from https://www.washingtonpost.com/news/thefix/wp/2016/02/10/hillary-clinton-has-a-majorhonesty-problem-after-new-hampshire/

Cohn, R. (2016). Using Social Media to \#LeadChange. The New York Times. Retrieved August 22, 2016, from

https://nytimesineducation.com/spotlight/usin g-social-media-to-leadchange/

Croteau, D., \& Hoynes, W. (2014).

Media/Society. Industries, Images, and

Audiences. Fifth edition. Thousand Oaks, CA: Sage Publications.

Drize, D. (2019). This is the beginning of the construction of the future power vertical in 2024. Kommersant. Retrieved February 26, 2019, from

https://www.kommersant.ru/doc/3895082

Fairclough, N. (2001). Language and power. Second edition. London: Routledge.

Foucault, M. (1979). The history of sexuality, volume 1: An introduction. London: Allen Lane.

Fowler, R. (1991). Language in the news.

Discourse and ideology in the press. London and New York: Routledge.

Friedman, V. (2016). Hillary Clinton and Theresa May herald a new age in power dressing. The Sydney Morning Herald. Retrieved July 28, 2016, from

https://www.smh.com.au/world/hillary-clintonand-theresa-may-herald-a-new-age-in-powerdressing-20160728-gqfgq7.html

Gramsci, A. (1971). Selections from the Prison Notebooks. New York: International Publishers.

Hall, S. (1982). The Rediscovery of 'Ideology': Return of the Repressed in Media Studies. In Bennett T., Curran J. et al. (eds.), Culture, Society, and the Media. London: Routledge, 5690.

Hirschfeld, J.D., \& MacFarquhar, N. (2017). Trump Presses Putin on Russian Meddling in U.S. Election. The New York Times. Retrieved July 7, 2017, from 
https://www.nytimes.com/2017/07/07/world/e urope/g20-hamburg-trump-putin-protests.html

Hodge, R., \& Kress G. (1993). Language as Ideology. New York: Routledge.

Issers, O.S. (2009). Speech Impact. Moscow: Flint: Nauka.

Jordans, F. (2019). Thunberg 'a bit surprised' to be Time Person of the Year. The Star. Retrieved April 1, 2020, from

https://www.thestar.com/news/world/us/2019 /12/11/climate-activist-greta-thunberg-is-timeperson-of-the-year.html

Jung, C.G. (1979). Man and his Symbols. London: Aldus Books Limited.

Kara-Murza, S.G. (2018). Manipulation of consciousness: monograph. Moscow: Rodina.

Karasik, V.I. (1996). Cultural dominants in the language. Language personality: cultural concepts: Collection of scientific papers. Volgograd, Arkhangelsk: Change, 3-16.

Karasik, V.I. (2004). The language circle: personality, concepts, discourse. Moscow: Gnosis.

Lievrouw, L., \& Livingstone, S. (2006). Handbook of New Media. Social Shaping and Social Consequences of ICTs. London, UK: Sage.

Maslow, A. (2008). Motivation and Personality. St. Petersburg: Peter.

McLuhan M., \& Fiore Q. (1967). The medium is the message: An inventory of Effects. New York: Bantam.

Negm, M.S. (2015). Resisting power in discourse. Procedia - Social and Behavioral Sciences, 192, 284-289.

Perlez, J. (2012). Beijing Exhibiting New Assertiveness in the South China Sea. The New York Times. Retrieved May 31, 2012, from https://www.nytimes.com/2012/06/01/world/a sia/beijing-projects-power-in-strategic-southchina-sea.html

Philo, G. (2007). Can Discourse Analysis Successfully Explain the Content of Media and Journalistic Practice? Journalism Studies, 8(2), 175-196.
Picoult, J. (2009). Change of heart. Reprint edition. New York: Washington Square Press.

Rubnikovich, O. (2010). All honour must know and conscience. The Supreme Court clarified that claims for the protection of honour and dignity should not kill the media. Kommersant. Retrieved September 18, 2010, from https://www.kommersant.ru/doc/1506980

Rudakova, A.V. (2004). Cognitive science and cognitive linguistics. Voronezh: Origins.

Savage M., \& Fisher L. (2016). Cameron resigns after Brexit defeat. The Times. Retrieved June 24, 2016, from https://www.thetimes.co.uk/article/cameronto-step-down-after-brexit-defeat-mgm2pqbnf

Sedov, K.F. (2004). Discourse and personality: the evolution of communicative competence. Moscow: Labyrinth.

Seliverstova, I. (2016). Why Medvedev sent school teachers to the business. Moskovskij Komsomolets. Retrieved August 4 2016, from https://www.mk.ru/social/2016/08/04/zachem -medvedev-poslal-uchiteley-v-biznes.html

Shabanova, A.A. (2011). Representation of the concept of 'power' in the contemporary Russian language picture of the world. Bulletin of Chelyabinsk State University, Philology. Art History, 17 (232), Issue 55, 172-175.

Sheigal, E.I. (2000). The semiotics of political discourse: monograph. Volgograd: Change.

Sheigal, E.I. (2001). Power as a concept and category of discourse. Essay on the social power of language. Voronezh: VSU.

Simpson A., \& Mayr A. (2010). Language and Power. London; New York: Routledge Taylor \& Francis Group.

Slyshkin, G.G. (2002). Gender concept sphere of the modern Russian anecdote. Gender as an Intrigue of Cognition: Gender Studies in Linguistics, Literary Studies and Communication Theory, 66-73.

Stepanov, Yu.S. (2015). Semiotics. Moscow: Lenand. 
The Moscow Times. (2019). Russia's Aeroflot will cancel Boeing 737 Max order if safety issue not solved. Retrieved March 15, 2019, from https://www.themoscowtimes.com/2019/03/1 5/russias-aeroflot-will-cancel-boeing-737-maxorder-if-safety-issue-not-solved-a64828

Tokarev, G.V. (2000). Problems of the linguacultural description of the concept (on the example of the concept of "labour activity"). Tula: TSPU named after L.N. Tolstoy.

Vale, E. (2017). Donald Trump uses presidential power to commute a prison sentence for the first time. Rare.US. Retrieved December 21, 2017, from https://rare.us/rarenews/president-trump-commutes-firstsentence-for-federal-prisoner-heres-what-weknow/

Van Dijk, T.A. (2008). Discourse and Power. Contributions to Critical Discourse Studies. Houndsmills: Palgrave MacMillan.

Van Dijk, T.A. (2009). Society and Discourse. How social contexts control text and talk. Cambridge: Cambridge University Press.

Vodak, R. (1997). Language. Discourse. Politics. Volgograd: Change.

Will, G.F. (2013). Obama's extreme use of executive discretion. The Washington Post.
Retrieved February 19, 2016, from

https://www.washingtonpost.com/opinions/ge orge-will-obamas-extreme-use-of-executivediscretion/2013/12/18/656ae4be-680d-11e3ae56-22de072140a2_story.html?noredirect=on

\section{Acknowledgements}

This study was financially supported by the Ministry of Education and Science of the Russian Federation on the state project 5-100 to improve the competitiveness of RUDN University among the world's leading research and education centres in 2016-2020. The authors are profoundly grateful to the anonymous reviewers for their valuable feedback, which helped us to improve the paper. The authors have no conflict of interest.

\section{Author Contribution Statement}

Alla Guslyakova: conceptualisation, methodology, conducting empirical research; Maria Rudneva: curation of data, developing the first draft; Julia Zakirova: visualisation of data; Nailya Valeeva: contribution in software and validation of data; Nina Guslyakova: developing the final draft alongside editing and reviewing; Irina Vashunina: guidance and supervision. 